\title{
Phenology of Caulerpa taxifolia and temporal dynamics of its epibiontic meiofauna in the port of Malinska (Croatia, northern Adriatic Sea)*
}

\author{
ANA TRAVIZI and NEVENKA ZAVODNIK \\ “Ruđer Bošković” Institute, Center for Marine Research, G. Paliaga 5, Rovinj 52210, Croatia. E-mail: travizi@ cim.irb.hr
}

\begin{abstract}
SUMMARY: The qualitative and quantitative composition of epibiontic meiofauna were studied in the $C$. taxifolia settlement recently recorded in the Malinska port (Krk Island, northern Adriatic Sea). The samples were taken monthly, from May 1998 till June 1999 covering the complete life cycle of $C$. taxifolia. In total, 14 meiofaunal taxa were recorded. The meiofauna assemblage was characterized by the dominance of Copepoda (58\%), the subdominant position of Nematoda (25\%), and the low single participation of other taxa. The results of monthly monitoring indicated a seasonal trend in meiofaunal distribution. The beginning of the summer was a period of a low meiofaunal abundance (139 ind. sample $\left.{ }^{-1}\right)$, and also a start of its exponential increase. The autumn was characterized by a fairly high abundance ( 1000-1500 ind. sample $\left.{ }^{-1}\right)$ and moderate variation of the constituent taxa levels. During the winter exponential growth (to about 10000 ind. sample ${ }^{-1}$ ) and high faunal diversity was detected. In subsequent months meiofaunal abundance reached over 19.000 ind. sample ${ }^{-1}$ - remaining extremely high until May when C. taxifolia fronds disappeared. The increase of meiofaunal abundance was positively correlated with the increase of the algal frond's length during the summer-autumn period, and with the increasing quantity of sediment particles and detritus accumulated on algal fronds during the $C$. taxifolia vegetative cycle. This study has shown that $C$. taxifolia can provide a suitable habitat for numerous benthic invertebrates, although it is known as a species that reduces the benthic biodiversity.
\end{abstract}

Key words: Caulerpa taxifolia, epibiontic meiofauna, temporal dynamics, northern Adriatic.

RESUMEN: FENOlogía de CAULERPa TAXIFOLIA Y DINÁMICA TEMPORAL DE SU MEIOFAUNA EPIBIONTE EN EL PUERTO DE Malinska (CROACIA, MAR AdRiático SEPTENTRIONAL). - Se estudió la composición cualitativa y cuantitativa de la meiofauna epibionte en la implantación de Caulerpa taxifolia recientemente registrada en el puerto de Malinska (isla de Krk, mar Adriático septentrional). Se tomaron muestras mensuales, desde mayo de 1998 a junio de 1999, cubriendo el ciclo biológico completo de $C$. taxifolia. En total, se registraron 14 táxones de meiofauna. La comunidad de la meiofauna se caracterizó por la dominancia de copépodos $(58 \%)$, la posición subdominante de los nemátodos (25\%) y la participación reducida de los demás grupos. Los resultados del seguimiento mensual indicaron una tendencia estacional en la distribución de la meiofauna. El inicio del verano fue un período de abundancia reducida de la meiofauna (139 ind. muestra $\left.{ }^{-1}\right)$, y también el comienzo de su aumento exponencial. El otoño se caracterizó por una abundancia relativamente elevada ( 1000-1500 ind. mues$\operatorname{tra}^{-1}$ ) y por la variación moderada de los niveles taxonómicos constituyentes. Durante el invierno se detectó un crecimiento exponencial (hasta cerca de 10.000 ind. muestra ${ }^{-1}$ ) y una elevada diversidad faunística. En los meses siguientes la abundancia de la meiofauna alcanzó unos 19.000 ind. muestra ${ }^{-1}$, y siguió muy alta hasta mayo, cuando desaparecieron los frondes de $C$. taxifolia. El aumento en la abundancia de la meiofauna estuvo correlacionado positivamente con el aumento de la longitud de los frondes algales durante el período de verano-otoño, y con la cantidad creciente de partículas de sedimento y detritos acumulados en los frondes durante el ciclo vegetativo de $C$. taxifolia. Este estudio ha demostrado que $C$. taxifolia. puede proporcionar un hábitat adecuado para numerosos invertebrados bentónicos, aunque se la conoce como especie que reduce la biodiversidad bentónica.

Palabras clave: Caulerpa taxifolia, meiofauna epibionte, dinámica temporal, Adriático septentrional. 


\section{INTRODUCTION}

The green alga Caulerpa taxifolia (Vahl) C. Agardh, which was originally found in the tropics, was observed for the first time in the Mediterranean in 1984 (Meinesz and Hesse, 1991). It appears that the initial colony descended from a polyploidic culture which was accidentally released into the Mediterranean from an aquarium in Monaco (Meinesz and Hesse, 1991; Boudouresque et al., 1995). The invasive nature of the newcomer was demonstrated by its impressive spreading potential. In 1984 this species covered $1 \mathrm{~m}^{2}$ of the sea bottom, and in subsequent years it spread annually by a factor of 2-10 (Boudouresque et al., 1995). Nowadays its presence is reported in 103 independent areas along $191 \mathrm{~km}$ of coastline in six Mediterranean countries, occupying about 13000 ha (Meinesz et al., 2001). This expansionistic success is firstly due both to an extremely efficient mode of vegetative propagation and to the remarkable adaptability to a new environment. These are considerably reinforced by weak pressure from grazers (due to excretion of repulsive secondary metabolites) and fairly unsuccessful efforts for eradication (Meinesz and Hesse, 1991; Guerriero et al., 1992, 1993). During its growth, Caulerpa outcompeted native seaweeds and seagrasses, displacing invertebrate communities, and seriously reducing the diversity of benthic habitats (Bellan-Santini et al., 1994; Boudouresque et al., 1992, 1995; Verlaque and Fritayre, 1994).

Shortly after its introduction into the Mediterranean, $C$. taxifolia became one of the most interesting subjects in marine biology. It became the focal point of many projects, seminars, and symposia including four thematic workshops accompanied by special publications (Boudouresque et al., 1994, 1997; Ribera et al., 1996; Gravez et al., 2001). Although the existing literature on $C$. taxifolia covers a wide variety of scientific disciplines, e.g. morphology, taxonomy, ecology, chorology, ecotoxicology, physiology, etc., only a scanty information is available on the influence of the algal spread on sediment living meiofauna (Poizat and Boudouresque, 1996; Travizi 1996). Our study preceded preliminary observations of epibiontic meiofauna performed in August 1997 (Zavodnik et al.,1998), and July-August 1998 (Zavodnik et al., 2001). The results of the latter concerned the initial period of meiofauna colonization that were completed and elaborated in this study. The present study is part of a long-term monitoring project on the $C$. taxifolia settlement in the coastal area of Malinska, and is focussed on the temporal dynamics of epibiontic meiofauna and its dependence on the phenology of Caulerpa taxifolia.

\section{AREA INVESTIGATED}

In the coastal area of Malinska (Krk Island, northern Adriatic Sea) C. taxifolia was observed for the first time in November 1994 (Zavodnik et al., 1997). The initial settlement was almost totally restricted to the interior of the Malinska port, and only a few isolated tufts were detected in the vicinity of the inner port entrance. In March 1996 this settlement was successfully removed using suction pumps, but a few months later a new, dense settlement of about $1200 \mathrm{~m}^{2}$ was detected near the external breakwater (Zavodnik et al., 1998). This settlement has progressively spread to depths of between 4 and $15 \mathrm{~m}$. At the beginning of this study (summer 1998) C. taxifolia overdominated the native seagrasses (Cymodocea nodosa and Zostera noltii) and the seaweeds of the photophilic algal communities, and extended to cover $6480 \mathrm{~m}^{2}$ of the bottom area (Iveša, 2001). Nevertheless, the local biodiversity did not seem to be largely influenced (Zavodnik et al., 1998). Apart from two seagrasses and seven fish species, more than 50 algal species, and more than 150 species of macrobenthic invertebrates were noted within the settlement discussed in this study (Iveša, 2001).

The sampling site was located within a compact and dense $C$. taxifolia settlement, spreading out on the silty-sandy bottom beyond the Malinska port entrance $\left(45^{\circ} 7^{\prime} 30^{\prime \prime} \mathrm{N}, 14^{\circ} 31^{\prime} 56^{\prime \prime} \mathrm{E}\right)$ at a depth of $4 \mathrm{~m}$.

\section{MATERIALS AND METHODS}

The phenology of $C$. taxifolia and the variability of environmental parameters (temperature, salinity) were monitored monthly, from May 1998 to June 1999. Algal material for morphometric measurements and the analysis of associated meiofauna was taken on each occasion, except May 1998 and May 1999 when only the necrotic and disintegrated remains of Caulerpa were found. The investigation concentrated on algal fronds as the representative part of thalli where the epibiontic organisms settled. Stolons were not collected due to the impossibility of distinguishing genuine epibionts from sediment 
living meiobenthos which accidentally settled on the stolon surface. Samples taken for morphometric measurements and meiofauna analysis included 3 subsamples of twenty fronds each.

The temperature of the water near the bottom was measured with a reversing thermometer, and the salinity was determined using a Yeo-kal induction salinometer.

The material was collected manually by SCUBA divers. The sampling procedure was performed very carefully to avoid any disturbance or contamination by the surrounding substrate during manipulation. The seaweed fronds were enclosed in transparent polyvinyl bags tightened around the "stalks", while the fronds were cut off close to the insertion point (Kangas, 1978). After fixation in buffered $4 \%$ formalin solution and staining in Rose Bengal the fronds were rinsed with tap water using a $100 \mu \mathrm{m}$ sieve until defaunation and sediment removal were completed. Then they were subjected to standard morphometric measurements: length, width, wet weight, dry weight and surface area estimation. The surrounding water, collected together with Caulerpa fronds, was filtered through the same mesh sieve. The collected sediment and meiofauna were transferred into a Petri dish. The meiofauna was counted and sorted using a Wild stereo microscope, at 2550x magnification. After meiofauna separation the remaining sediment was transferred into a measuring cylinder. The quantity of sediment was measured throughout the volume of sediment, and was expressed as mean of three subsamples.

The frond surface area was determined by means of imprints -shaped by transferring the original frond contours onto paper. The "frondprints" were carefully cut out and weighed on an analytical balance at 0.0001 accuracy. The weight measured was interpolated according to the formula usually used in leaf surface area determination (Marković et al., 1981):

$$
\mathrm{S}_{1}=\mathrm{P}_{1} * \mathrm{~S} / \mathrm{P},
$$

where $S_{1}$ is frond surface area, $P_{1}=$ weight of fronds imprints, $S=$ surface area of control paper square, i.e. $100 \mathrm{~cm}^{2}$, and $\mathrm{P}=$ weight of the paper square with a known surface.

Algal morphometric measurements were subjected to descriptive statistical analyses and were presented as means of three subsamples with corresponding standard errors. Raw data of meiofauna abundance were $\sqrt{ } \sqrt{ }$ and $\log _{10}$ transformed, and appropriate statistical analyses (Cluster analysis, ANOVA and multiple comparison test) were performed (Petz, 1985; Clarke and Warwick, 1990).

\section{RESULTS}

\section{Abiotic parameters}

The annual distribution of environmental parameters measured during the sampling period is shown in Figures 1a, b. Water temperatures ranged from 9 to $21^{\circ} \mathrm{C}$, maintaining the highest values $\left(\geq 20^{\circ} \mathrm{C}\right)$ from mid June to late September. Fairly high temperatures $\left(19^{\circ} \mathrm{C}\right)$ persisted till the end of October, when a consistent decrease began $\left(1-2^{\circ} \mathrm{C}\right.$ per month). This lasted during the winter, and culminated in a minimum $\left(9^{\circ} \mathrm{C}\right)$ in March 1999 . In April, the temperature started to increase and in the second half of May it reached $15^{\circ} \mathrm{C}$. The salinity of the water sediment interface ranged between 37.1 and 38.5, attaining somewhat higher values during the winter season.

\section{Phenology of Caulerpa taxifolia}

During the annual cycle, successive changes were observed in the colour, texture, ramification and vitality of the primary fronds. In May 1998, at the sampling site, the seabed was overgrown by a dense network of defoliated and partially necrotic stolons persisting from the previous settlement. At the time of the described final phase in settlement degradation, apical growth of stolons provided an initial plant material for starting a new vegetative cycle of $C$. taxifolia. This happened at the beginning of June, when the first primary fronds appeared from the recently elongated basal part of the thalli. These fronds were distinguished by a luminous light green colour and their vital appearance: their surface was bright, smooth, almost without accumulated detritus and apparently free from fouling and epibiontic organisms. However, microscopic examination revealed a fairly abundant meiobenthic community. Over the summer and autumn months the fronds assumed a less intensive colour and started to ramify, but they still kept their vitality and "clear" appearance due to a low quantity of sediment deposited on their surface. During the winter-spring period deposition of fine particles of organic detritus and sediment on the fronds' surface gradually increased, and by the end of winter the fronds' vital- 

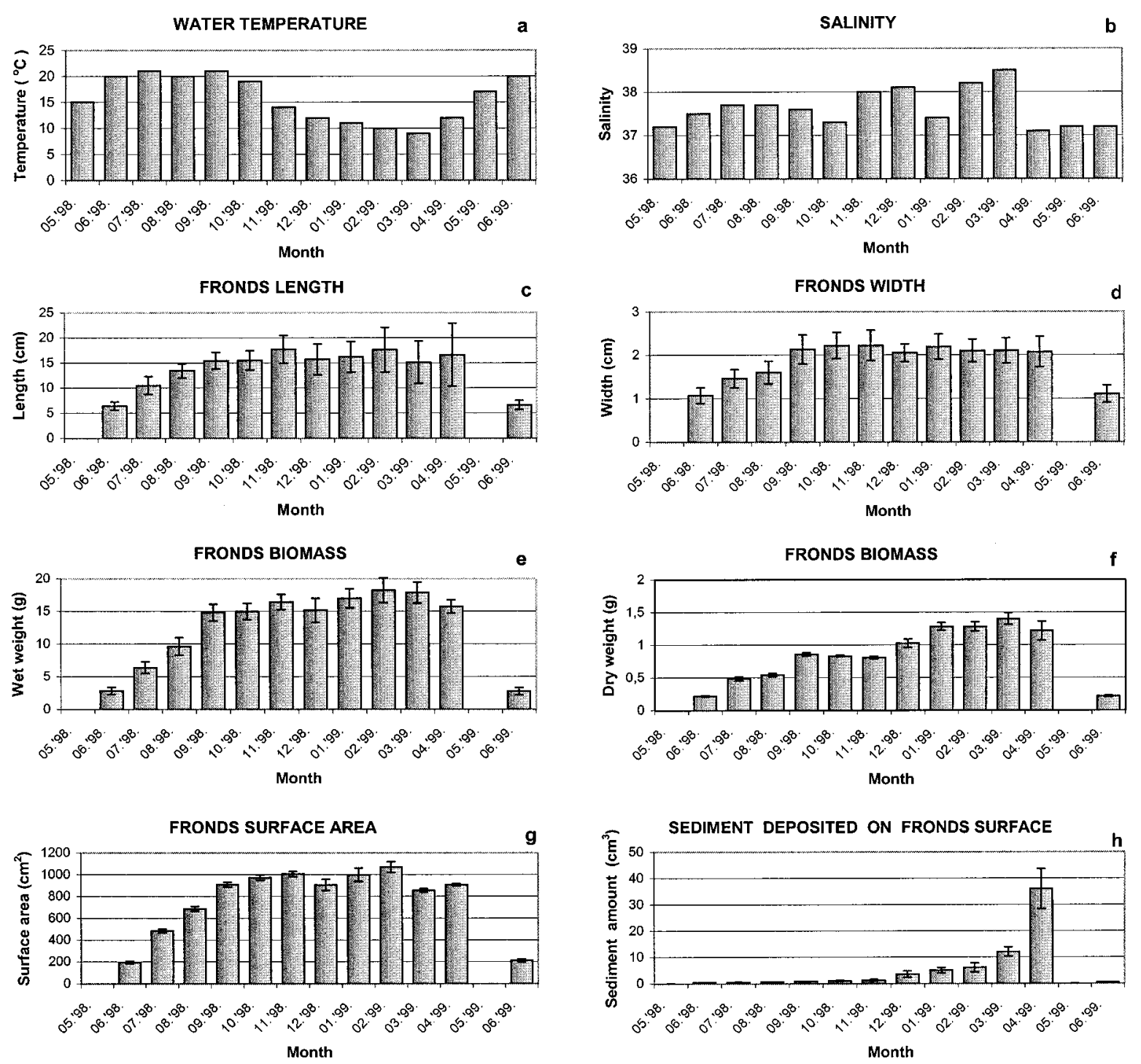

FIG. 1. - Temporal variability of environmental and morphometrical parameters monitored during the vegetative cycle of Caulerpa taxifolia in Malinska port (Krk Island, northern Adriatic). Error bars represent the variation ( \pm 1 S.E.) among three subsamples.

ity drastically declined. Fronds collected in March were sluggish, fragile and were covered by a thick layer of detritus and sediment particles agglutinated by a sticky mucous material, probably produced by the excretion from Caulerpa. Most of the fronds were subjected to transverse fragmentation of their distal parts and/or to the unilateral loss of vertical segments containing 5-10 pinnules. In April, the fronds were overloaded with organic detritus and sediment particles, almost touching down to the sediment surface. In May 1999, as well as in May 1998, sampling area was covered by a network of defoliated and partially necrotic stolons -the last remains of the Caulerpa settlement monitored during its complete life cycle. Control sampling obtained in June 1999 corresponded with data noted twelve months ago, both in the morphometry of primary fronds and the abundance of epibiontic organisms.

The annual distribution of the main morphometric parameters, i.e. length, width, biomass, and the surface area of primary fronds is plotted in figs. 1cg. Minimum values were noted in June 1998, and they averaged as follows: length $6.4 \mathrm{~cm}$, width 1.1 $\mathrm{cm}$, wet weight $2.81 \mathrm{~g}$, and dry weight $0.21 \mathrm{~g}$. During the summer and autumn primary fronds progressively elongated till the end of November, when they reached a maximum of $17.7 \mathrm{~cm}$. In the winter-spring period (from December 1998 to April 1999) the growth was discontinued and the primary fronds varied from 15.1 to $17.6 \mathrm{~cm}$ in length (Fig. 1c.). The same pattern was observed in respect to other measured variables, i.e. width (Fig. 1d), biomass (Figs. 


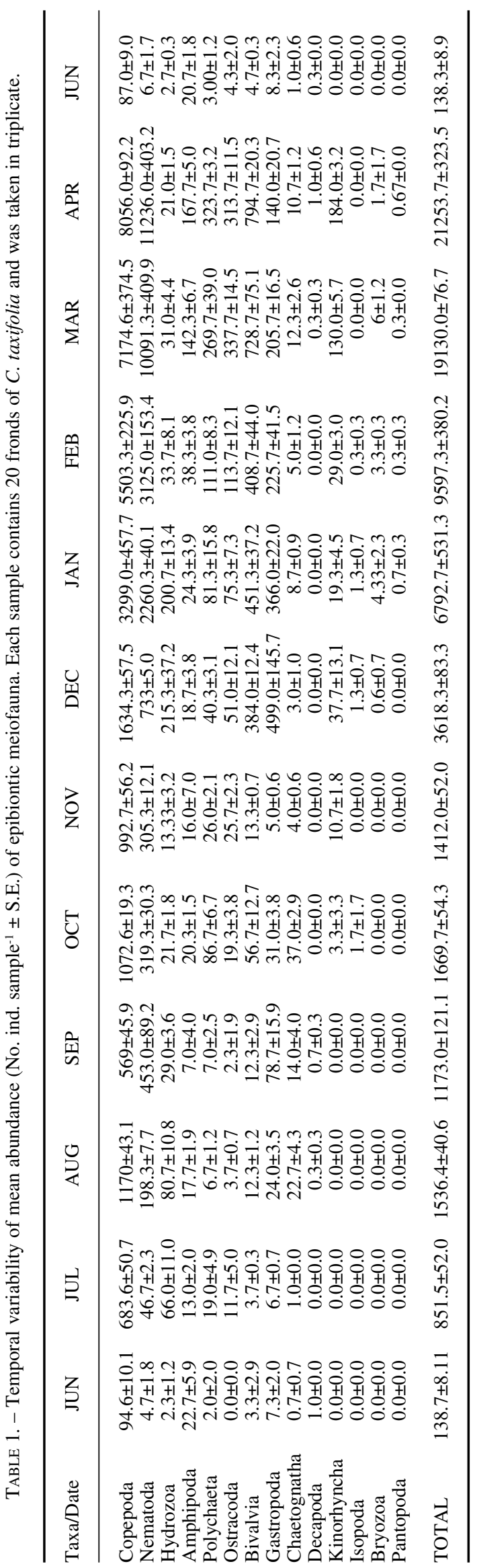

1e,f) and surface area (Fig. 1g) of primary fronds. The biomass and frond surface area reached maximal values in February 1999.

The quantity of organic detritus and fine sediment particles deposited on the algal fronds increased progressively throughout the life cycle of C. taxifolia (Fig. 1h). During the summer and autumn the quantity of deposited material was very low $\left(<1.2 \mathrm{~cm}^{3}\right.$ month $\left.^{-1}\right)$, but consistent increase of $0.1 \mathrm{~cm}^{3}$ month $^{-1}$ (summer), and $0.2 \mathrm{~cm}^{3}$ month $^{-1}$ (autumn) was recorded. In winter, the quantity of deposit ranged between 3.6 and $6 \mathrm{~cm}^{3}$ month $^{-1}$, when gradual increase of $1 \mathrm{~cm}^{3}$ month $^{-1}$ was observed. In spring, the process of deposition progressively increased by a factor of 2 from February to March $\left(12 \mathrm{~cm}^{3}\right.$ month $\left.^{-1}\right)$, and by factor of 3 from March to April $\left(36 \mathrm{~cm}^{3}\right.$ month $\left.^{-1}\right)$.

\section{Seasonal dynamics of meiofauna}

The mean abundance of 14 meiobenthic taxa recorded in monthly samples collected during the annual growth cycle of Caulerpa taxifolia shows a temporal variability (Table 1). The total meiofauna density varied between 139 (June 1998) and 21524 ind. sample $^{-1}$ (April 1999), mostly displaying an exponential trend of increase. This trend was disrupted during the autumn when meiofauna density showed a minor variability and mean values became close to values recorded in August.

With the exception of a somewhat isolated position of samples corresponding to the initial phase of meiofauna colonization (June 1998 and June 1999), multivariate analysis of epibiontic meiofauna revealed distinct clustering in four groups mainly corresponding to summer, autumn, winter and spring (Fig. 2). As September results were clustered with the results of the summer months, deviation from an ideal seasonal clustering pattern was observed. In order to confirm clustering, ANOVA and the multiple comparison test were calculated between each pair of samples. ANOVA results pointed out statistically significant differences in total meiofauna abundance (Table 2). The multiple comparison test revealed no significant differences between samples belonging to the same season (except samples from June 1998 and June 1999) in contrast to differences calculated for each pair of samples belonging to different seasons, where statistical significance was found (Table 3). The only exception is the sample from August which relates to the autumn samples. 


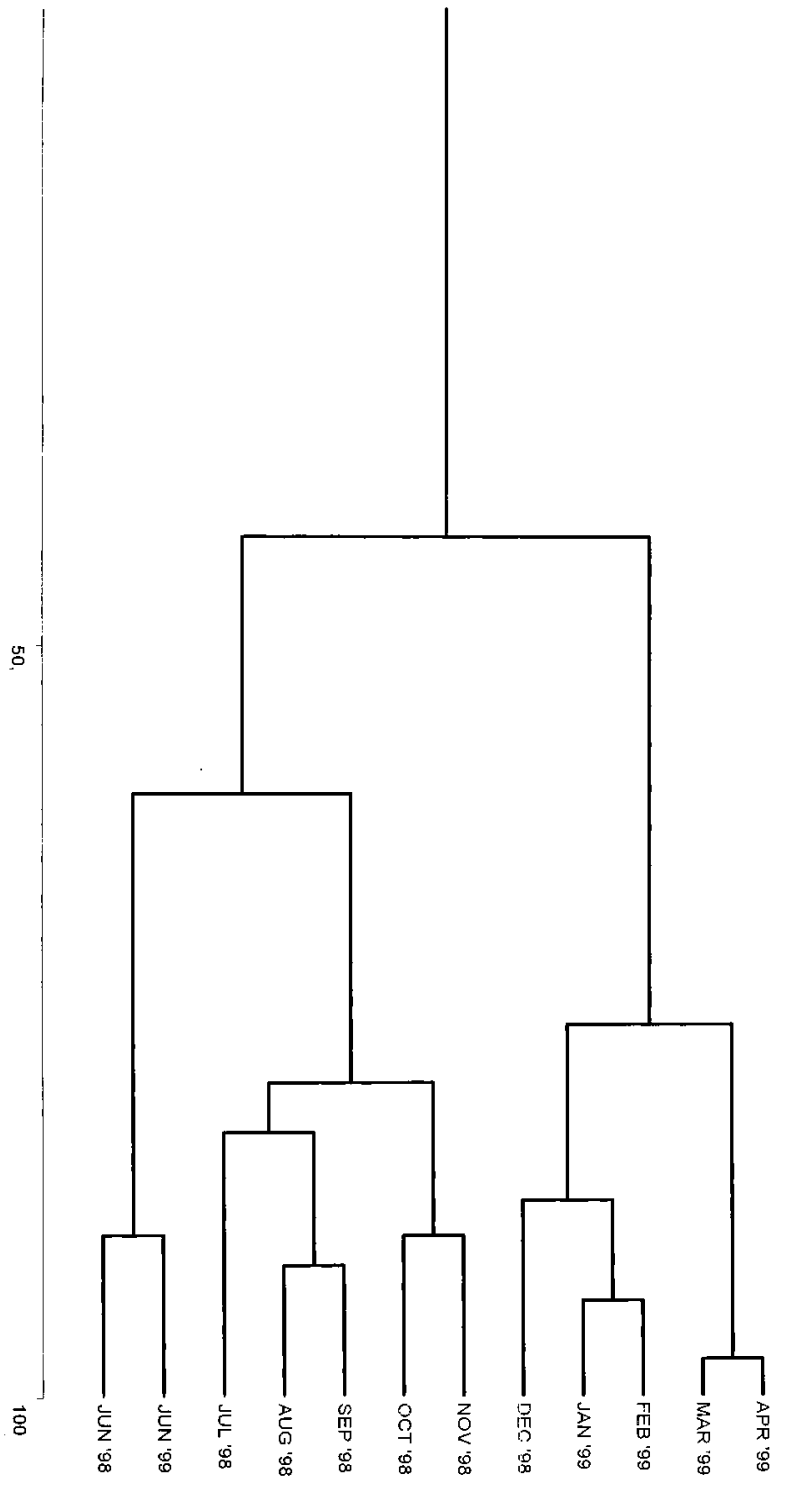

FIG. 2. - Hierarchical agglomerative clustering of epibiontic meiofauna. The raw data were $\sqrt{ }$ transformed. The affinity level, based on composition and abundance of meiofauna was expressed as the Bray-Curtis similarity between monthly samples.
TABLE 2. - ANOVA test for differences in total meiofauna densities during the research period. Raw data log 10 transformed. No of replicates $=3$. Statistically significant differences at $\mathrm{p}<0.05_{(24,11)}=$ $2.22(*)$.

\begin{tabular}{lrrrr}
\hline Source of variations & SS & df & MS & F \\
\hline Between groups & 17.271 & 11 & 1.570 & $976.67^{*}$ \\
Within groups & 0.039 & 24 & 0.002 & \\
Total & 17.310 & 35 & 1.572 & \\
\hline
\end{tabular}

A statistically significant correlation at $\mathrm{p}<0.01$ $(r=0.99)$ was found between the quantities of the material deposited on algal fronds and total meiofauna abundances. Figure 3 a shows a strong linear correlation between the two variables during the whole vegetative cycle of $C$. taxifolia, except in April 1999 when sedimentation increase was so high that the linear correlation disappeared, despite a significant increase of meiofauna abundance. Significant correlation at $\mathrm{p}<0.01(\mathrm{r}=0.92)$ also was found between total meiofauna abundance and length of algal fronds during the summer-autumn period (Fig. $3 \mathrm{~b}$ ), but this was not observed during the winter and spring seasons.

Due to its maximal frequency and conspicuous dominance, the reading for Copepoda (58\%) reached and maintained a distinctive position in meiofauna assemblage structure over the entire period of research. Nematoda were second in abundance, ranging from 3 to $53 \%$ (avg. 25\%) of the total meiofauna, and in terms of evenness its temporal distribution was quite asymmetric. The relative abundance of nematofauna successively increased in autumn due to a decrease in Copepoda abundance, and in the winter-spring season due to an exceptional increase of its own absolute abundance. The other constitutive taxa were distinguished by a low individual participation, and cumulatively contributed

TABLE 3. - Multiple comparison test (after Scheffè) for total meiofauna abundance between every pair of samples. Statistical significant differences at $\mathrm{p}<0.05, \mathrm{~F}^{\prime}=24.30(*)$.

\begin{tabular}{|c|c|c|c|c|c|c|c|c|c|c|c|c|}
\hline & JUN`98 & JUL'98 & AUG‘98 & SEP‘98 & OCT'98 & NOV‘98 & DEC'98 & JAN‘99 & FEB'99 & MAR'99 & APR'99 & JUN`99 \\
\hline JUN '98 & - & $*$ & $*$ & $*$ & $*$ & $*$ & $*$ & * & $*$ & $*$ & * & \\
\hline JUL '98 & 465.86 & - & & $*$ & $*$ & $*$ & $*$ & $*$ & $*$ & $*$ & $*$ & $*$ \\
\hline AUG '98 & 818.26 & 14.53 & - & & & & $*$ & $*$ & $*$ & $*$ & $*$ & $*$ \\
\hline SEP ‘98 & 644.95 & 49.30 & 10.30 & - & & & $*$ & $*$ & $*$ & $*$ & $*$ & $*$ \\
\hline OCT '98 & 875.87 & 64.18 & 0.98 & 17.63 & - & & $*$ & $*$ & $*$ & $*$ & $*$ & $*$ \\
\hline NOV'98 & 761.84 & 36.21 & 1.01 & 4.86 & 3.97 & - & $*$ & $*$ & $*$ & $*$ & $*$ & * \\
\hline DEC '98 & 1517.12 & 301.59 & 107.02 & 183.72 & 87.52 & 128.79 & - & $*$ & $*$ & $*$ & $*$ & $*$ \\
\hline JAN'99 & 2142.25 & 610.12 & 312.56 & 436.33 & 278.54 & 349.05 & 53.79 & - & $*$ & $*$ & $*$ & $*$ \\
\hline FEB '99 & 2539.61 & 830.06 & 474.78 & 624.93 & 432.62 & 519.52 & 130.97 & 16.89 & - & $*$ & $*$ & $*$ \\
\hline MAR '99 & 2433.85 & 1370.13 & 899.63 & 1102.45 & 841.23 & 960.85 & 386.08 & 151.65 & 67.31 & - & & $*$ \\
\hline APR '99 & 3584.14 & 1464.38 & 976.30 & 1187.15 & 915.42 & 1040.03 & 436.84 & 184.05 & 89.42 & 1.57 & - & $*$ \\
\hline JUN'99 & 0.00 & 467.10 & 819.89 & 646.40 & 877.56 & 763.42 & 1519.35 & 2144.90 & 2542.50 & 3437.21 & 3588.57 & - \\
\hline
\end{tabular}



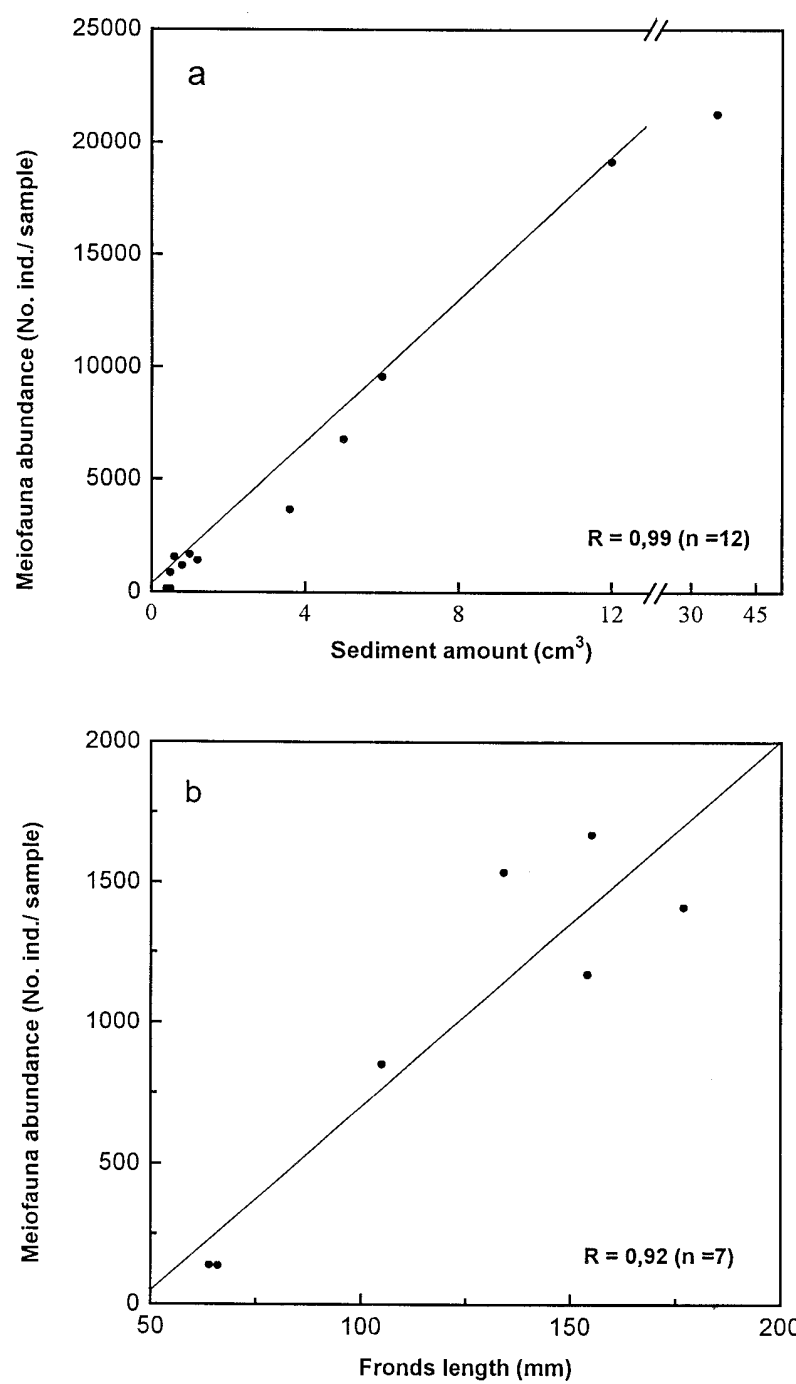

FIG. 3. - The relationship between the total meiofauna abundance and: (a) the quantity of sediment deposited on the algal fronds during the vegetative cycle of C.taxifolia, and (b) the length of algal fronds in summer-autumn period. only to $17 \%$ in the total meiofauna (Table 4). However, some of these taxa were distinguished by comparatively high densities (Amphipoda, Hydrozoa, Polychaeta, juvenile Gastropoda, juvenile Bivalvia, Chaetognatha), and their representatives were recorded during the whole period of investigation. Except in September, the abundance of Amphipoda was fairly consistent, but in terms of dominance a more prominent position was achieved only in June 1998. In terms of absolute numbers, an increasing trend of abundance during the winter-spring period was observed in Polychaeta, and especially in Gastropoda and Bivalvia. The same trend was observed in Kinorhyncha (firstly recorded in October) and Ostracoda (represented in all samples, excluding the first one), but nevertheless, their percentage share in total meiofauna abundance remained symbolic. Sporadically, the community structure was enriched by representatives of Isopoda, juvenile Decapoda, Pantopoda and Bryozoa, but from the quantitative standpoint, their participation was negligible. During the investigation, many epiphytic algae, large numbers of diatoms and foraminifers, and sometimes even juvenile fish cohabited with meiobenthos, but were not taken into account.

\section{DISCUSSION}

The vegetative cycle of Mediterranean C. taxifolia can be defined as pseudoperennial, meaning that in spite of indefinite apical growth of the stolons, no single part of the alga persists physically for more than one year (Meinesz et al., 1995). In its native habitats $C$. taxifolia is a perennial, monoecious

TABLE 4. - Temporal variability of percentage abundance of epibiontic meiofauna per sample. Each sample contains 20 fronds of $C$. taxifolia and was taken in triplicate.

\begin{tabular}{|c|c|c|c|c|c|c|c|c|c|c|c|c|c|}
\hline Taxa/Date & JUN & JUL & AUG & SEP & OCT & NOV & DEC & JAN & FEB & MAR & APR & JUN & Average \\
\hline Copepoda & 68.27 & 80.30 & 76.16 & 48.51 & 64.24 & 70.30 & 45.17 & 48.57 & 57.34 & 37.50 & 37.90 & 62.89 & 58.10 \\
\hline Nematoda & 3.37 & 5.48 & 12.91 & 38.62 & 19.13 & 21.62 & 20.26 & 33.28 & 32.56 & 52.75 & 52.87 & 4.82 & 24.80 \\
\hline Hydrozoa & 1.68 & 7.75 & 5.25 & 2.47 & 1.30 & 0.94 & 5.95 & 2.95 & 0.35 & 0.16 & 0.10 & 1.93 & 2.57 \\
\hline Amphipoda & 16.35 & 1.53 & 1.15 & 0.60 & 1.22 & 1.13 & 0.52 & 0.36 & 0.40 & 0.74 & 0.79 & 14.94 & 3.31 \\
\hline Polychaeta & 1.44 & 2.23 & 0.43 & 0.60 & 5.19 & 1.84 & 1.11 & 1.20 & 1.16 & 1.41 & 1.52 & 2.17 & 1.69 \\
\hline Ostracoda & 0.00 & 1.37 & 0.24 & 0.20 & 1.16 & 1.82 & 1.41 & 1.11 & 1.18 & 1.77 & 1.48 & 3.13 & 1.24 \\
\hline Bivalvia & 2.40 & 0.43 & 0.80 & 1.05 & 3.39 & 0.94 & 10.61 & 6.64 & 4.26 & 3.81 & 3.74 & 3.83 & 3.49 \\
\hline Gastropoda & 5.29 & 0.78 & 1.56 & 6.71 & 1.86 & 0.35 & 13.79 & 5.39 & 2.35 & 1.08 & 0.66 & 6.02 & 3.82 \\
\hline Chaetognatha & 0.48 & 0.12 & 1.48 & 1.19 & 2.22 & 0.28 & 0.08 & 0.13 & 0.05 & 0.06 & 0.05 & 0.72 & 0.57 \\
\hline Decapoda & 0.72 & 0.00 & 0.02 & 0.06 & 0.00 & 0.00 & 0.00 & 0.00 & 0.00 & 0.00 & 0.00 & 0.00 & 0.07 \\
\hline Kinorhyncha & 0.00 & 0.00 & 0.00 & 0.00 & 0.20 & 0.76 & 1.04 & 0.28 & 0.30 & 0.68 & 0.87 & 0.00 & 0.34 \\
\hline Isopoda & 0.00 & 0.00 & 0.00 & 0.00 & 0.10 & 0.00 & 0.04 & 0.02 & 0.00 & 0.00 & 0.00 & 0.00 & 0.01 \\
\hline Bryozoa & 0.00 & 0.00 & 0.00 & 0.00 & 0.00 & 0.00 & 0.02 & 0.06 & 0.03 & 0.03 & 0.02 & 0.00 & 0.01 \\
\hline Pantopoda & 0.00 & 0.00 & 0.00 & 0.00 & 0.00 & 0.00 & 0.00 & 0.01 & 0.00 & 0.00 & 0.00 & 0.00 & 0.00 \\
\hline TOTAL & 100.00 & 100.00 & 100.00 & 100.00 & 100.00 & 100.00 & 100.00 & 100.00 & 100.00 & 100.00 & 100.00 & 100.00 & 100.00 \\
\hline
\end{tabular}


species, with moderate covering and sociability rates, and with combined, sexual and asexual reproduction (Meinesz and Hesse, 1991; Boudouresque and Bellan-Santini, 1992). The Mediterranean strain of $C$. taxifolia, apart from its modified vegetative cycle, has higher coverage, productivity, sociability rate; longer fronds, and lack of sexual reproduction (Boudouresque et al., 1995; Meinesz et al., 1995). The northern Adriatic population of Caulerpa corresponded in some differential characters (modified vegetative cycle, high productivity rate and lack of sexual reproduction) to the western Mediterranean population. Some other features (comparatively short fronds and stolons, moderate covering and sociability rates) makes it closer to a tropical than to a western Mediterranean population (Zavodnik et al., 1998). However, the phenology of C. taxifolia in the Malinska coastal area largely corresponded to reports from other Mediterranean habitats (Boudouresque et al., 1995).

The annual growth cycle of $C$. taxifolia in the Malinska coastal area regularly started at the end of May or beginning of June, and it terminated eleven months later (Iveša, 2001). Thus, in the local population, a transitive period between two successive generations lasts for about one month, and for that reason, in the northern Adriatic, the terminal phase of the latent period is considerably reduced. In other shallow Mediterranean habitats $(<8 \mathrm{~m})$ complete disappearance of fronds occurred at the most during the entire winter-spring season (Meinesz et al., 1995).

In the native tropical habitat, the distribution of C. taxifolia is limited by the $20^{\circ} \mathrm{C}$ isotherm, while in the Mediterranean this species still survives at $7^{\circ} \mathrm{C}$, but does not begin to grow until the temperature reaches about $15^{\circ} \mathrm{C}$ (Boudouresque et al., 1995). In the Malinska region, the beginning of the growing season was triggered by increase of the water temperature to $15^{\circ} \mathrm{C}$ (initiation of stolon growth), and $16-17^{\circ} \mathrm{C}$ (appearance of initial fronds) respectively, as elsewhere in the Mediterranean (Boudouresque $e t$ al., 1995).

Generally, the vegetative cycle of $C$. taxifolia consists of an active phase that takes place in the summer-autumn period, and a latent phase that occurs in the winter-spring season (Zavodnik et al., 1998). The results of this study indicated that the annual cycle of $C$. taxifolia can be divided into four distinctive phases mainly corresponding to seasons. Due to the qualitative nature of the nonnumeric parameters that characterize the algal phenology (colour, vitality, ramification, etc.), the supposed seasonal pattern cannot be statistically tested. A seasonal pattern was revealed in the temporal distribution of epibiontic meiofauna. From the abundance data, three distinctive periods can be discerned (summer-autumn, winter and spring). However, an exponential increase of meiofauna abundance during the summer months in contrast to stagnation (positive and negative insignificant alterations) during the autumn, appeared as an important distinctive character between the summer and autumn and could support the existence of a four-season pattern.

Composition and dynamics of meiofauna are highly dependent on the physical properties of the microhabitat (McIntyre, 1969; Kangas, 1978). Sediment dwelling and epibiontic communities are subjected to different environmental conditions. They are distinguished by specific structure and dynamics that require a different approach and methodology. Any comparison of results concerning epibiontic meiofauna presented in this paper with data concerning sediment dwelling meiofauna in the C. taxifolia settlement (Poizat and Boudouresque, 1996; Travizi 1996) are baseless. The only comparable results with data presented in this article are the results obtained in our preliminary research (Zavodnik et al., 1998). They are in accordance with the results of this study, both in the morphometry of the primary fronds and the qualitative and quantitative composition of meiofauna.

The abundance of meiofauna is highly correlated with the elongation of primary fronds (summer and autumn), and the deposited particle amounts present on the fronds' surface (June to March). Both the lengths of the primary fronds and the sediment amount improve the physical properties of microhabitat, i.e. with available space increase in three dimensions, the contact area becomes more suitable for many interstitial species and non-swimmers lacking in adhesive glands. In addition, deposits can be used as shelter and the main food resource for many selective and non-selective deposit feeders, trophic categories mostly dominant in meiofauna communities.

The summer period (June-August 1998) was distinguished by appearance, proliferation and fast elongation of the primary fronds. This period had started with a low meiofaunal abundance (139 ind. sample ${ }^{-1}$ ), but followed by an exponential increase. Such an increase was probably stimulated by optimal conditions (low competition, plenty of available space and food) that prevail on a weakly colonized substrate. 
The autumn period (September-November 1998) should be defined conditionally as the period of stagnancy, and it was distinguished by deceleration in growth of primary fronds, as well as by minor alterations in the temporal dynamics of meiofauna. The inclusion of this period into the active phase of algal vegetative cycle can be attributed to an increasing frequency of secondary growth, e.g. up to the ramification of the fifth order per single primary frond (Iveša, 2001). A deviation from the general trend that has prevailed in summer months was first shown by a slight decrease of the total meiofauna density in September, primarily caused by a considerable decrease in Copepoda density. A significant decrease of the absolute abundances was also recorded in Hydrozoa, Amphipoda and Chaetognatha. At the same time, other numerically important taxa, i.e. Nematoda and Gastropoda displayed significant increases in their abundance in comparison with the results noted in August. The short-term decrease in meiofauna density could be linked with a supposed repellent effect of secondary metabolites on particular meiobenthic taxa, since the concentration of secondary metabolites is maximal during the summer-autumn period (Boudouresque et al., 1992). These findings should be taken into account as a reason for the short-term, unexpected decline in density of some meiobenthic taxa, as well as for their reduced colonisation rate in comparison with all other seasons. We intend to verify this hypothesis in further research. The results of many studies have already indicated a relatively high sensitivity of copepods to different environmental stressors in comparison with other meiobenthic taxa, especially nematodes (McIntyre, 1977; McLachlan et al.; 1977, Heip, 1980; Raffaelli and Mason, 1981; Sandulli 1986; Poizat and Boudouresque; 1996, Travizi, 2000). Leaving aside the short-term decline in abundance of Copepoda, the autumn period generally should be denoted as the period of meiofauna stagnancy.

The winter period (December 1998 - February 1999) was distinguished by a decreasing of C. taxifolia vitality and appearance of necrotic lesions on the fronds surface. During this season, an exponential increase of meiofaunal density has been repeatedly observed. This increase could be stimulated by increasing heterogeneity of the microhabitat due to high fouling and sedimentation rates, but this also was enhanced by food resources, i.e. detritus, sediment associated bacteria, diatoms, foraminifera and meiofauna itself.
The spring period (March-May 1999) may be designated as a terminal phase of the $C$. taxifolia life cycle, and a climax stage in the development of epibiontic communities. It was characterized by a successive degradation of Caulerpa settlement, an excessive deposition of detritus and sediment particles on the fronds' surface, and the abundance explosion in total meiofauna density, especially of nematodes. Predominance of nematodes is the main distinctive character of sediment living meiobenthos (Heip et al., 1995). Their supremacy in the terminal phase of the $C$. taxifolia life cycle was expected since the primary substrate changed from algal fronds to a sediment layer accumulated on them.

In this article we described the formation and development of a specific epibiontic community. Its appearance and existence are tightly linked to the establishment and maintenance of $C$. taxifolia settlement in the northern Adriatic. Although C. taxifolia is known as a species that reduces the diversity of macrobenthos (Bellan-Santini et al., 1994; Boudouresque et al., 1992, 1995; Verlaque and Fritayre, 1994) our data show that it can provide a suitable habitat for many benthic invertebrates.

\section{ACKNOWLEDGEMENTS}

The author thanks Andrej Jaklin for sampling the material, and to Rosella Sanković and Mirjana Fonjak for laboratory assistance. We are grateful to Dr. Dušan Zavodnik, Ljiljana Iveša and Maja Fafanđel for their valuable suggestions and discussion. We are greatly obliged to Jill Glen-Peruško for final English editing, and especially to Dr. Enric Ballesteros and one anonymous reviewer for precious suggestions and the final improvement of the manuscript. The support of the Ministry of Science and Technology of the Republic of Croatia Project No. 00981302 is acknowledged.

\section{REFERENCES}

Bellan-Santini, D., P.M. Arnaud, G. Bellan and M. Verlaque. 1994. Résultats préliminaires sur la faune d'invertébrés du peuplement à Caulerpa taxifolia des côtes de Provence (Méditerranée Nord-Occidentale). In: C.F. Boudouresque, A. Meinesz and V. Gravez (eds.), First International Workshop on Caulerpa taxifolia pp. 365-369. GIS Posidonie, Marseilles.

Boudouresque, C.F., D. Bellan-Santini. - 1992. The introduction of the green alga Caulerpa taxifolia into the Mediterranean: the repercussions for the indigenous communities. Mésogée, 52: 88-89.

Boudouresque, C.F., A. Meinesz and V. Gravez. - 1994. First International Workshop on Caulerpa taxifolia. GIS Posidonie, Marseilles. 
Boudouresque, C.F., A. Meinesz, M.A. Ribera and E. Ballesteros. 1995. Spread of the green alga Caulerpa taxifolia (Caulerpales, Chlorophyta) in the Mediterranean: possible consequences of a major ecological event. Sci. Mar., 59(Supl. 1): 21-29.

Boudouresque, C.F., V. Gravez, A. Meinesz and F. Palluy. - 1997. Third International Workshop on Caulerpa taxifolia. GIS Posidonie, Marseilles.

Clarke, K.R. and R.M. Warwick. - 1990. Lecture notes prepared for the training on the statistical treatment and interpretation of marine community data. FAO/IOC/UNEP, Split.

Gravez V., S. Ruitton, C.F. Boudouresque, L. le Diréach, A. Meinesz, G. Scabbia and M. Verlaque (eds.) - 2001. Fourth International Workshop on Caulerpa taxifolia. GIS Posidonie, Marseilles.

Guerriero, A., A. Meinesz, M. D’Ambrosio and F. Pietra. - 1992. Isolation of toxic and potentially toxic sesqui- and monoterpenes from the tropical green seaweed Caulerpa taxifolia which has invaded the region of Cap Martin and Monaco. Helv. Chim. Acta, 75: 689-695.

Guerriero, A., F. Marchetti, M. D'Ambrosio, S. Senesi, F. Dini and F. Pietra. - 1993. New ecotoxycologically and biogenetically relevant terpenes of the tropical green seaweed Caulerpa taxifolia which is invading the Mediterranean. Helv. Chim. Acta, 75: 855-864.

Heip, C. -1980 . Meiobenthos as a tool in the assessment of marine environmental quality. Rapp. P.-v. Réun. Cons. int. Explor. Mer, 183: 51-56.

Heip. C., M. Vincx and G. Vranken. - 1995. The ecology of marine nematodes. Oceanogr. Mar. Biol. Ann. Rev., 23: 399-489.

Iveša, Lj. - 2001. Analiza naselja tropske zelene alge Caulerpa taxifolia (Vahl.) C. Ag. (Malinska, otok Krk). M.sc. thesis, University of Zagreb.

Kangas, P. - 1978. On the quantity of meiofauna among the epiphytes on Fucus vesiculosus in the Askö Area, North Baltic Sea. Contrib. Askö Lab. Univ Stockholm, 10: 1-32.

Marković, D., Z. Vukmirović, D. Veselinović, M. Janković, R. Popović, Z. Gradojević, J. Dimitrijević and V.V. Đorđević. 1981. Detekcija $i$ kontrola životne sredine. Naučna knjiga, Beograd.

McIntyre, A.D. - 1977. Effects of pollution on inshore benthos. In: B.C. Coull (ed.), Ecology of marine benthos, pp. 301-318. Columbia, Univ. S. Carolina, Belle W. Baruch Lib. Mar. Sci.

McIntyre, A.D. - 1969. Ecology of marine meiobenthos. Biol. Rev., 44: 245-290.

McLachlan, A., P.E.D. Winter and L. Botha. - 1977. Vertical and horizontal distribution of sublitoral meiofauna in Algoa bay. III - A quantitative analysis of the nematode and crustaceans communities. Zool. Afr., 12: 61-71.

Meinesz, A. and B. Hesse. - 1991. Introduction et invasion de l'algue tropicale Caulerpa taxifolia en Méditerranée Occidentale. Oceanol. Acta, 14: 415-426.

Meinesz, A., L. Benichou, J. Blachier, T. Komatsu, R. Lemée, H. Molenaar and X. Mari. - 1995. Variations in the structure, morphology and biomass of Caulerpa taxifolia in the Mediter- ranean Sea. Botanica Marina, 38: 499-508.

Meinesz A., T. Belsher, B. Antolić, K. Ben Mustapha, C. F. Boudouresque, D. Chiaverini, F. Cinelli, J.M. Cottalorda, A.Djellouli, A. El Abed, C. Orestano, A.M. Grau, Lj. Iveša, A. Jaklin, H. Langar, E. Massuti-Pascual, A. Peirano, T. Thibaut, L. Tunesi, J. de Vaugelas, N. Zavodnik and A. Žuljević. - 2001. The introduced green alga Caulerpa taxifolia continues to spread in the Mediterranean. Biological invasions, 3: 201-210.

Petz, B. - 1985. Osnovne statističke metode za nematematičare. Sveučilišna naklada Liber, Zagreb.

Poizat, C. and C.F. Boudouresque. - 1996. Meiofaune du sediment dans des peuplements à Caulerpa taxifolia du Cap Martin (Alpes-Maritimes, France). In: M.A. Ribera, E. Ballestereos, C.F. Boudouresque, A. Gómez and V. Gravez (eds.), Second International Workshop on Caulerpa taxifolia, pp. 375-386. Publicacions Universitat de Barcelona. Barcelona.

Raffaelli, D and C.F. Mason. - 1981. Pollution monitoring with meiofauna using the ratio of nematodes to copepods. Mar.Pollut. Bull., 12: 158-163.

Ribera, M.A., E. Ballestereos, C.F. Boudouresque, A. Gómez and V. Gravez. - 1996. Second International Workshop on Caulerpa taxifolia. Publicacions Universitat de Barcelona. Barcelona.

Sandulli, R. - 1986. Pollution and meiofauna: a short review. Nova Thalassia, 8: 312-323.

Travizi, A. - 1996. Meiofauna i nematofauna sedimenta u naselju alge Caulerpa taxifolia (luka Malinska, otok Krk). In: M. ArkoPijevac, M. Kovačić and S. Leiner, (eds.), Natural History researches of the Rijeka region $\mathrm{pp}$. 55. Prirodoslovni muzej, Rijeka.

Travizi, A. - 2000. Effect of anoxic stress on density and distribution of sediment meiofauna. Period. biol. 102: 207-215.

Verlaque, M. and P. Fritayre. - 1994. Incidence de 1 'algue introduite Caulerpa taxifolia sur le phytobenthos de Méditerranée Occidentale: 2. Les peuplements d'algues photophiles de l'infralitoral. In: C.F. Boudouresque, A. Meinesz and V. Gravez, (eds.), First International Workshop on Caulerpa taxifolia, pp. 349-353. GIS Posidonie, Marseilles.

Zavodnik, N., A. Jaklin and Ž. Labura. - 1997. Pojava tropske alge. Caulerpa taxifolia u Riječkom zaljevu. In: M. Arko-Pijevac, M. Kovačić and S. Leiner (eds.), Natural History researches of the Rijeka region pp. 717-722. Prirodoslovni muzej, Rijeka.

Zavodnik, N., A. Travizi, A. Jaklin and Ž. Labura. - 1998. Caulerpa taxifolia (Chlorophyta) in the north Adriatic Sea (Krk Island, Croatia). In: C.F. Boudouresque, V. Gravez, A. Meinesz and F. Palluy (eds.), Third International Workshop on Caulerpa taxifolia, pp. 175-184. GIS Posidonie, Marseilles.

Zavodnik, N., Lj. Iveša, A. Travizi and A. Jaklin - 2001. Recent study on Caulerpa taxifolia (Chlorophyta) settlement at Malinska, Croatia (north Adriatic Sea, Krk Island ). In: V. Gravez, S. Ruitton, C.F. Boudouresque, L. Le Diréac'h, A. Meinesz, G. Scabbia and M. Verlaque (eds.), Fourth International Workshop on Caulerpa taxifolia, pp. 118-127. GIS Posidonie, Marseilles. 